\title{
A CROSS-SECTIONAL STUDY ON THE RELATIONSHIP BETWEEN SMARTPHONE ADDICTION AND DEPRESSION, ANXIETY AND SOCIAL APPEARANCE ANXIETY IN YOUNG ADULTS
}

\author{
GENÇ ERIŞKINLERDE AKILLI TELEFON BAĞIMLILIĞI ILE DEPRESYON, ANKSIYETE VE \\ SOSYAL GÖRÜNÜM KAYGISI ARASINDAKI ILIŞKI ÜZERINE KESITSEL BIR ÇALIŞMA
}

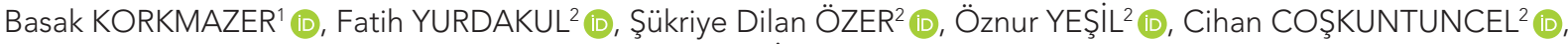 \\ Büşra Nur SUALP² (D), Ayşe ÖNDER² (D), Erkan Melih ŞAHIN² (D) \\ 'Basaksehir Cam and Sakura City Hospital, Department of Family Medicine, Istanbul, Turkey, \\ ${ }^{2}$ Canakkale Onsekiz Mart University, Faculty of Medicine, Department of Family Medicine, Canakkale, Turkey
}

ORCID IDs of the authors: B.K. 0000-0003-2977-0693; F.Y. 0000-0001-7104-4172; Ş.D.Ö. 0000-0002-7442-3765; Ö.Y. 0000-0001-7447-2869; C.C. 0000-0002-7684-8994; B.N.S. 0000-0002-8174-0814; A.Ö. 0000-0002-0834-6159; E.M.Ş. 0000-0003-1520-8464

Cite this article as: Korkmazer B, Yurdakul F, Ozer SD, Yesil O, Coskuntuncel C, Sualp BN, et al. A cross-sectional study on the relationship between smartphone addiction and depression, anxiety and social appearance anxiety in young adults. J Ist Faculty Med 2022;85(1):91-7. doi: 10.26650/IUITFD.907719

\section{ABSTRACT}

Objective: The aim of this study was to determine the prevalence of smartphone addiction in young adults, and to investigate the relationship between smartphone use, depression, anxiety, and social appearance anxiety.

Materials and Methods: Sociodemographic data form, Smartphone Dependence Scale-Short Form, Beck Depression Inventory for Primary Care-Short Form, Beck Anxiety Scale, and Social Appearance Anxiety Scale were applied face to face in this cross-descriptive study.

Results: A total of 259 subjects, 128 (49.4\%) female and 131 (50.6\%) male, were included in the study. $25.9 \%$ of the participants were smartphone addicts. There was a high positive correlation between smartphone usage time and smartphone addiction score. The social appearance anxiety average scores of the social media users $(30.8 \pm 13.9)$ were higher than those of subjects who do not use social media (28.8 \pm 11.3$)$. Smartphone addiction scale had a positive correlation with anxiety and social appearance anxiety scores, while not with depression.

Conclusion: Our results revealed that the purpose of smartphone usage affects people more than smartphone usage or smartphone addiction. The internet, and especially programs related to sharing one's appearance and lifestyle and applications that create an unrealistic appearance that conforms to virtual norms, can add hard-to-repair prejudices to the mind. This situation should be seen as a threat, especially for the

\section{ÖZET}

Amaç: Bu çalışma ile, genç yetişkinlerde akıllı telefon bağımlılığının yaygınlığını belirlemek ve akıllı telefon kullanımı, depresyon, anksiyete ve sosyal görünüş kaygısı arasındaki ilişkiyi araştırmak amaçlandı.

Gereç ve Yöntem: Çapraz tanımlayıcı desende planlanan bu çalışmada sosyo-demografik veri formu, Akıllı Telefon Bağımlılık Ölçeği-Kısa Formu, Birinci Basamak için Beck Depresyon Envanteri-Kısa Formu, Beck Anksiyete Ölçeği ve Sosyal Görünüş Kaygısı Ölçeği yüz yüze uygulanmıştır.

Bulgular: Çalışmaya 128'i $(\% 49,4)$ kadın ve $131(\% 50,6)$ erkek olmak üzere toplam 259 kişi dahil edildi. Katılımcıların \%25,9'u akıllı telefon bağımlısıydı. Akıllı telefon kullanım süresi ile akıllı telefon bağımlılığı puanı arasında yüksek bir pozitif korelasyon vardı. Sosyal medya kullanıcılarının sosyal görünüş kaygısı ortalama puanları $(30,8 \pm 13,9)$, sosyal medya kullanmayanların puanlarından $(28,8 \pm 11,3)$ istatistiksel olarak daha yüksekti. Akıllı telefon bağımlılığı ölçeği ile depresyon ölçek puanları arasında anlamlı ilişki yokken, anksiyete ve sosyal görünüş kaygısı puanları ile pozitif korelasyona sahipti.

Sonuç: Çalışmamızda, akıllı telefon kullanımının amacının, akıllı telefon kullanımı veya bağımlılığına kıyasla kişileri daha fazla etkileme olasıığının olduğunu ortaya koymuştur. İnternet ve özellikle de görünüş ve yaşam tarzının paylaşımıyla ilişkili programların, olduğundan farklı ve normlara uygun görünüşün yaratıldığı uygulamalarla desteklenmesi zihinlere tamiri zor ön yargılar ek-

Corresponding author/iletişim kurulacak yazar: basakkorkmazer@gmail.com

Submitted/Başvuru: 13.04.2021 • Revision Requested/Revizyon Talebi: 07.05.2021 •

Last Revision Received/Son Revizyon: 11.06.2021 • Accepted/Kabul: 06.07.2021 • Published Online/Online Yayın: 19.01.2022 
younger generation, and is a new sociological problem worth investigating.

Keywords: Smartphone addiction, social media, anxiety, depression, social appearance anxiety leyebilir. Bu durum özellikle de genç nesil için bir tehdit olarak görülmelidir ve araştırılmaya değer yeni bir sosyolojik sorundur.

Anahtar Kelimeler: Akıllı telefon bağımlılığı, sosyal medya, anksiyete, depresyon, sosyal görünüş kaygısı

\section{INTRODUCTION}

In addition to facilitating communication, smartphones have become an important part of our lives in terms of having fun and making daily life easier. With the convenience provided by advancing smartphone technology, people can spend time on social media, manage their e-mail, use academic search databases, find answers to their questions easily via the internet, meet almost all their needs with online shopping, and access various entertainment tools through their smartphones. Although this versatile use of smartphones facilitates the life of human beings, it may negatively affect functionality in daily activities and relationships by predisposing individuals to become dependent on their smartphones, and increased use of smartphones is associated with various physical and psychiatric problems (1, 2). Smartphone addiction, which can be so severe as to make it difficult for the user to meet his or her own needs, can have a permanent negative impact. Excessive phone use, inability to keep away from the phone, and frequent control of the phone can be observed in smartphone addicts ${ }^{3}$. In addition to these, the results of various studies show that excessive use of smartphones and addiction to their content is related to anxiety disorder and depression $(3,4)$. According to data from the Turkey Statistical Institute, the percentage of a smartphone or mobile phone ownership grew from $53.7 \%$ in 2004 to $96.9 \%$ in $2016(2,5)$. The group with the most widespread use of smartphones is generation $Y$, born between 1977-1994, and generation Z, born in 1995 and later (6). In particular, generation $Z$ is the generation most vulnerable to smartphone addiction, as it has grown up with today's technology and the internet age.

Body perception consists of physical appearance, health status, physical skills, and sexual attitude, and is formed by the individuals' feelings, thoughts, and intuitions about their own body $(7,8)$. The anxiety and stress that individuals feel when their physical appearance is being evaluated by others is called social appearance anxiety and is closely related to depression and anxiety $(8,9)$. It should be noted that social media applications, which have become easier to reach with the widespread use of smartphones, may also change body perception by causing individuals' dissatisfaction about their appearance. In addition, it should be noted that some mobile applications that enable changes in appearance might impair body perception over time. The given risk increases, especially when the physical appearance becomes easily criticized by anonymous identities as a result of the easy integration of mass media into daily life with technologies such as smartphones (10). This study's aim was to determine the frequency of smartphone addiction in the young adult population, in which smartphone use is the most common, and examine the relationship between smartphone use and depression, anxiety, and social appearance anxiety.

\section{MATERIALS AND METHODS}

The study, which was planned in a cross-sectional-descriptive design, was carried out for one month in August 2019 with the approval of the Çanakkale Onsekiz Mart University Faculty of Medicine Clinical Research Ethics Committee (Date:24.07.2019, No: 14), with young adults who applied to the Family Medicine outpatient clinic of a tertiary hospital, met the appropriate participation conditions, and gave consent. Sociodemographic data was obtained. Questions involving smartphone usage features prepared by practitioners, the Smartphone Addiction Scale-Short Form, the Beck Depression Inventory-Short Form for Primary Care, and the Beck Anxiety Scale and Social Appearance Anxiety Scale were administered face to face to 259 people between the ages of 18 and 45 who gave their consent, had a smartphone, and did not have any diagnosis that would hinder their assessment of reality $(5,8,11,12)$. The participants' smartphone usage duration was recorded objectively using the pre-installed measurement application on their phones. Smartphone users without this feature were not included in the study.

The Smartphone Addiction Scale-Short form is a 10-item scale using a 6-point Likert scale developed by Kwon et al. to measure the risk of smartphone addiction in young adults. The items of the scale were scored from 1 to 6 . The total range of total score is $10-60$. The increase in the score obtained from the test is evaluated in direct proportion as the risk of addiction increases. This is a single-factor scale without subscales. In the Korean sample, the cut-off score was determined as 31 for male and 33 for female. The Cronbach alpha coefficient of the original form's internal consistency and concurrent validity is 0.91 (13). The Turkish validity and reliability study of the scale was conducted by Noyan et al. and Cronbach's alpha coefficient of the scale was 0.867 and had a 0.926 reliability coefficient (5). 
The Beck Depression Inventory for Primary Care (BDIPC) performs depression screening under seven items using the symptoms of sadness, pessimism, past failure, self-dislike, self-criticalness, loss of interest, and suicidal thoughts or wishes. Each heading includes a four-digit rating from 0 to 3 . The BDI-PC score is obtained by adding the highest scores in each item. Although no cut-off score is reported, the probability of depression in scores above 4 is evaluated as over $90 \%$ (11).

The Beck Anxiety Scale aims to determine the frequency and severity of anxiety symptoms experienced by individuals. The highest score that can be obtained from the scale, which consists of 21 items, is 63. Ulusoy et al., who completed the scale's Turkish validity and reliability study, identified the Cronbach alpha internal consistency as 0.93 . In the scale scoring, 0-7 points are evaluated as no anxiety, 8-15 points as mild anxiety, 16-25 points as moderate anxiety, and $26-63$ points as severe anxiety (12).

The Social Appearance Anxiety Scale was developed to measure the emotional, behavioral, and cognitive anxieties of individuals regarding their appearance based on self-reported answers. The scale has 16 Likert-type questions and was developed in 2008 by Hart et al. (14). The validity, reliability, and adaptation study of the scale to Turkish was carried out by Tayfun Dogan in 2010 (8). The internal consistency coefficient of the scale is 0.93 and the reliability coefficient is 0.88 . The minimum score of the scale is 16 and the maximum score is 80 . Higher scores indicate a higher level of social appearance anxiety (8).

After the interviews with the participants were completed, the research data was digitized. Frequency and percentage values were calculated for categorical variables, and mean and standard deviation values were calculated for continuous variables. Analyses were performed using Chi-square, Student t-test, ANOVA, Kruskal Wallis, Pearson, and Spearman correlation tests following data properties. Since the sample size was larger than 30 , the normal distribution assumption was neglected in parametric tests based on the central limit theorem (15). $p<0.05$ was accepted as the limit of significance for all analyses and absolute $p$ values were given for each analysis.

\section{RESULTS}

A total of 259 people (128 (49.4\%) female, 131 (50.6\%) male) were included in the study. The mean age of the participants was $30.7 \pm 7.0$ [18-42]. While 55 (21.2\%) individuals belong to generation Z, 204 (78.8\%) were part of generation Y. 104 participants (40.2\%) were single, 140 (54.1\%) were married, and 15 (5.8\%) were widowed. Regarding their educational status, 44 (17.0\%) were primary school graduates, 61 (23.6\%) were high school graduates,
119 (45.9\%) were university graduates, and 35 (13.5\%) had master's degrees and doctoral degrees.

Sixty-seven (25.9\%) of the participants were smartphone addicts. Forty-two (62.7\%) of the addicts were female and 25 (37.3\%) were male; there was a significant difference between the genders $\left(\chi^{2}=6.363 ; p=0.01\right)$. There was a significant negative correlation between smartphone addiction total scores and age $(r=-0.247 ; p<0.001)$. The smartphone addiction rate in generation $Z(45.5 \%)$ was significantly higher than that of generation $Y(20.6 \%) \quad\left(\chi^{2}=13.968\right.$; $p<0.001)$. There was a statistically significant difference between marital status and smartphone addiction $\left(\chi^{2}=8.855\right.$; $p=0.012): 37(35.6 \%)$ of the single participants, 28 of the married participants (20.0\%), and 2 (13.3\%) of the widowed participants were smartphone addicts. Eight (18.2\%) of the primary school graduates, 13 (21.3\%) of the high school graduates, 41 (34.5\%) of the university graduates, and 5 $(14.3 \%)$ of the master-doctoral graduates were smartphone-addicted, and there was a significant difference between the groups $\left(\chi^{2}=9.039 ; p=0.029\right)$.

Of the participants, 211 (82.4\%) reported using their smartphone to access social media, $95(37.1 \%)$ to play video games, 181 (70.7\%) to surf the web, $119(46.5 \%)$ to do shopping-related activities, and $52(20.4 \%)$ to meet new people. Smartphone addiction was higher in those who used their phone to access social media content, play video games, surf the web, do shopping-related activities, and meet new people $\left(\chi^{2}=16.207 ; p<0.001\right.$, $\chi^{2}=14.949 ; \quad p<0.001, \quad \chi^{2}=13.198 ; \quad p<0.001, \quad \chi^{2}=15.601 ;$ $p<0.001$ and $\chi^{2}=16.773 ; p<0.001$, respectively).

The mean screen time of the participants was 189.6 \pm 124.2 [30-960] minutes per day. Mean screen time (271.6 \pm 134.3 minutes per day) was significantly higher in patients with smartphone addiction than those without addiction ( $155.4 \pm 102.3$ minutes per day) ( $t=-6.654$; $\mathrm{p}<0.001)$. There was a high positive correlation between smartphone use time and smartphone addiction score $(r=0.512 ; p<0.001)$. There was a significant negative correlation between age and the duration of smartphone use $(r=-0.324 ; p<0.001)$. The daily smartphone use time of generation $Z(251.5 \pm 129.9$ minutes) was significantly higher than generation $Y(172.8 \pm 117.5$ minutes $)$ $(t=3.594 ; p<0.001)$. The mean screen time of females was $201.5 \pm 115.2$ minutes, while the mean of males was $178.8 \pm 131.7$ minutes $(t=1.293 ; p=0.198)$. Smartphone use was found to be $221.0 \pm 134.1$ minutes per day for singles, $163.4 \pm 15.2$ minutes for married people, and 193.2 \pm 81.8 minutes for widows $(F=5.175 ; p=0.006)$ (Table 1$)$.

Sixty-five (35.7\%) of the 253 participants who answered the BDI-PC had depressive symptoms above the threshold value. There was no significant difference between the genders $\left(\chi^{2}=0.294 ; p=0.587\right)$. There was no significant difference between age and BDI-PC scores $(t=0.571$; 
Table 1: The relationship between the participants' average smartphone usage duration and their sociodemographic features

\begin{tabular}{llll}
\hline Intended use of smartphone & $\begin{array}{l}\text { Average smartphone usage } \\
\text { duration }(\min / \text { day })\end{array}$ & Statistical analysis \\
Gender & Woman & $201.5 \pm 115.2$ & $\mathrm{t}=1.293 ; \mathrm{p}=0.198$ \\
Generation & $\mathrm{Y}$ & $178.8 \pm 131.7$ & \\
\multirow{2}{*}{ Marital status } & $\mathrm{Z}$ & $251.5 \pm 129.9$ & $\mathrm{t}=-3.594 ; \mathrm{p}<0.001$ \\
& Single & $221.1 \pm 134.1$ & \\
& Married & $163.4 \pm 115.2$ & $\mathrm{~F}=5.175 ; \mathrm{p}=0.006$ \\
\multirow{2}{*}{ Educational status } & Widowed & $193.2 \pm 81.8$ & \\
& Primary school graduate & $134.0 \pm 106.8$ & \multirow{2}{2}{$=23.239 ; \mathrm{p}<0.001$} \\
& High school graduate & $180.2 \pm 107.8$ & \\
& University graduate & $227.9 \pm 142.7$ & \\
\hline
\end{tabular}

$p=0.569)$. Similarly, no statistically significant difference was found between marital status and educational status and the level of depressive symptoms $\left(\chi^{2}=2.633 ; p=0.268\right.$ and $\chi^{2}=6.429 ; p=0.093$, respectively). The evaluation of Beck Anxiety Scale scores showed that 130 of the participants (50.2\%) had no anxiety, 47 (18.1\%) had mild anxiety, $45(17.4 \%)$ had moderate anxiety, and $37(14.3 \%)$ had severe anxiety. Anxiety was present in $82(64.0 \%)$ of the female and $47(35.9 \%)$ of the male $\left(\chi^{2}=29.056 ; p<0.001\right)$ participants. While there was no significant difference between marital status and anxiety scale results $\left(\chi^{2}=2.521\right.$; $p=0.866)$, there was a significant negative correlation between educational status and anxiety $(r=-0.140 ; p=0.024)$. The average screen usage time and statistical analysis of the participants classified according to the Smartphone Addiction Scale-Short form, BDI-PC, and Beck Anxiety Scale are shown in Table 2.
The mean social appearance anxiety score of the participants in the study was $30.4 \pm 11$. While the mean score of females was $33.1 \pm 13.0$, the mean score of males was $27.7 \pm 9.9(t=3.797 ; p<0.001)$. While there is a significant negative correlation between social appearance anxiety scale total score and age $(r=-0.094 ; p=0.023)$, there was no statistically significant difference between generations ( $t=0.928 ; p=0.356$ ). The mean score of singles was $33.0 \pm 12.2$, the mean score of married participants was $28.6 \pm 11.5$, and the mean score of widows was $29.3 \pm 9.0$, and this score was higher in singles than in married participants and widows $(F=4.138 ; p=0.017)$. As the education level increased, the total scores of the social appearance anxiety scale increased significantly $(r=0.148 ; p=0.018)$.

The social media users' mean social appearance anxiety score was $30.8 \pm 13.9$, which was significantly higher

Table 2: The relationship between the participants' average smartphone usage duration and Smartphone Addiction, BDI-PC, and Beck Anxiety Scales

\begin{tabular}{|c|c|c|c|}
\hline Scales & & $\begin{array}{l}\text { Average smartphone usage } \\
\text { duration (min/day) }\end{array}$ & Statistical analysis \\
\hline \multirow[t]{2}{*}{ Smartphone addiction scale } & Non addicts & $271.6 \pm 134.3$ & $t=-6.654 ; p<0.001$ \\
\hline & Addicts & $155.4 \pm 102.3$ & \\
\hline \multirow{2}{*}{$\begin{array}{l}\text { Beck depression inventory for } \\
\text { primary care }\end{array}$} & Non depressive & $184.9 \pm 119.7$ & $t=-0.738 ; p=0.435$ \\
\hline & Depressive & $201.2 \pm 201.4$ & \\
\hline \multirow[t]{4}{*}{ Beck anxiety scale } & No anxiety & $180.0 \pm 12.0$ & $\chi^{2}=1.294 ; p=0.005$ \\
\hline & Mild anxiety & $154.8 \pm 19.2$ & \\
\hline & Moderate anxiety & $214.2 \pm 23.6$ & \\
\hline & Severe anxiety & $237.4 \pm 21.7$ & \\
\hline
\end{tabular}


Table 3: The relationship between the participants' smartphone use purposes and social appearance anxiety scale mean scores

\begin{tabular}{llll}
\hline \multicolumn{1}{l}{ Intended use of smartphone } & $\begin{array}{l}\text { Social appearance anxiety } \\
\text { score average } \\
\text { Social media }\end{array}$ & $30.8 \pm 13.9$ & Statistical analysis \\
& Users & $28.8 \pm 11.3$ & $\mathrm{t}=-1.057 ; \mathrm{p}=0.038$ \\
Gonusers & $31.5 \pm 12.7$ & $\mathrm{t}=-1.046 ; \mathrm{p}=0.297$ \\
Users & $29.9 \pm 11.3$ & \\
Internet surfing & Nonusers & $31.5 \pm 12.3$ & $\mathrm{t}=-2.134 ; \mathrm{p}=0.034$ \\
& Users & $28.0 \pm 10.4$ & \\
Shopping & Nonusers & $32.4 \pm 12.0$ & $\mathrm{t}=-2.450 ; \mathrm{p}=0.015$ \\
& Users & $28.8 \pm 11.5$ & \\
To meet new people & Nonusers & $32.0 \pm 11.4$ & $\mathrm{t}=-1.058 ; \mathrm{p}=0.291$ \\
& Users & $30.1 \pm 12.0$ & \\
\hline
\end{tabular}

than the mean score of $28.8 \pm 11.3$ of those who did not use social media ( $t=-1.057 ; p=0.038$ ). Similarly, the social appearance anxiety scale scores of those who use their smartphones for surfing the web and shopping were significantly higher than those who did not use smartphones for these purposes ( $t=-2.134 ; p=0.034$ and $t=-2.450$; $p=0.015)$. There was no statistically significant difference between the total mean score of the social appearance anxiety scale among those who used their smartphones to play video games and meet new people and the total mean scores of those who did not use smartphones for this purpose $(t=-1.046 ; p=0.297$ and $t=-1.058 ; p=0.291)$ (Table 3).

While no significant correlation was observed between the smartphone addiction scale and depression scale $(r=0.119 ; p=0.059)$, a statistically significant positive correlation was found between the anxiety scale and social appearance anxiety $(r=0.203 ; p=0.001$ and $r=0.335$; $p<0.001$ respectively).

\section{DISCUSSION}

The development of smartphones and their ensuing global popularity has changed the communication and information environment and had an impact on sociality, entertainment, access to information, and creating social identity. This situation has been accompanied by concerns about overuse and addiction. Smartphone addiction causes people to see their phones as a body part, leading to panic and stress in the absence of their smartphone. Smartphone addiction is a worldwide phenomenon that occurs in $9.3 \%$ to $48 \%$ of the population (16-18). In our study population, the percentage of smartphone addiction was found to be $25.9 \%$, and this rate is quite high. This high rate may be related to the fact that smartphone addiction is more common at a young age and that the age of the people included in our study is younger than the general population and therefore more easily adaptable to innovations. Increasing frequency of smartphone use and screen time is also closely related to the severity of smartphone addiction (19). Our study supports this data in that a statistically significant positive correlation was observed between the duration of smartphone use and the smartphone addiction score.

Female participants were found to have a higher rate of smartphone addiction compared to males; similarly, female participants' mean duration of smartphone usage was higher than males. Different results have been obtained in terms of gender in different studies on this subject. While some studies have concluded that smartphone addiction is more common in males, the frequency is greater in the female gender in different studies (13, $20,21)$. More studies are needed on the prevalence of smartphone addiction between the genders.

In our study, there was a negative correlation between smartphone addiction and age. One study found that younger age groups are more addicted to smartphones (22). Similarly, the mean duration of smartphone use was negatively correlated with age and decreased with age. This shows that young people integrate smartphones into their lives, and the risk of smartphone addiction increases as age decreases.

There was a significant difference between the marital status of the participants and their smartphone addiction. In our study, the highest rate of smartphone addiction and the highest mean duration of smartphone usage were observed in singles. This situation may be related to the relationship between age and marital status, and it suggests that marital status has a minimal effect on smartphone screen time and addiction. 
A significant positive correlation between depression and anxiety and smart device addiction has been shown in the study of a mixed sample of 274 adults aged 16-59 years, which was applied in the general adult population to define the relationship between depression and anxiety and smartphone addiction (23). Similarly, a systematic review in 2019 on problematic smartphone use emphasized both the direction and possible explanations of the relationship between psychopathology and problematic smartphone use (1). Although many studies have shown a relationship between smartphone use and depression and anxiety, no significant relationship was found with depression in our study. This can be explained by the cultural differences and the characteristics of the sample group. Our results reveal the idea that general smartphone use has become an ordinary part of life. The purpose of using smartphones affects people, rather than smartphone use or addiction. There is a strong relationship between addiction and anxiety, and it is known that anxiety disorder contributes to the increment in addiction $(24,25)$. In our study, similar results were obtained. However, current data is insufficient to determine whether problematic use increases anxiety or whether existing anxiety triggers smartphone use in the direction of addiction.

In comparing participants' reasons for smartphone use and social appearance anxiety, the mean social appearance anxiety scores were higher, especially among social media users and individuals doing online shopping, than those who used smartphones for other purposes. Social appearance anxiety is positively related to social anxiety criteria and negative body image (26). Similar to the finding in our study, extensive research on women's body image emphasized that young women are less satisfied with their bodies and want to look slimmer and that they are in a mood called "normative discontentment" $(27,28)$. Given that the idealized female body is almost unattainable, the vast majority of women are likely to experience appearance anxiety to some extent. Similarly, as the ideal appearance depicted in the media becomes physically uniform and unreachable, physical dissatisfaction might rise in men (29). It is an important problem that the posts, which are prepared in an unrealistic way using make-up and digital interventions, are published on social media channels with the expectation that they will be liked. Users circulate these posts by sharing them, without questioning whether the images are natural or modified. While those shared on smartphones and social media can facilitate social comparison by providing the opportunity to learn about the looks and experiences of others, this can also increase social appearance anxiety.

\section{CONCLUSION}

Increased use of smartphones and social media has enabled people to create a new identity in the virtual world and interact with other users. Given the positive relationship between psychological health and quality of life, it should be kept in mind that there is a potential risk of long-term negative effects of social networks. Abuse of mobile applications, especially those associated with sharing looks and lifestyle, may lead to prejudices that are hard to overcome. This poses a threat particularly for the younger generation and emerges as a new sociological problem worth investigating. This study documented the possible positive relationship between smartphone addiction and social appearance anxiety, and both conditions need to be elaborated on in future studies.

Informed Consent: Written consent was obtained from the participants.

Ethics Committee Approval: This study was approved by the Clinical Research Ethical Committee of the Çanakkale Onsekiz Mart University (COMU) (Date: 24.07.2019 No: 14).

Peer Review: Externally peer-reviewed.

Author Contributions: Conception/Design of Study- B.K., Ş.D.Ö., Ö.Y., A.Ö.; Data Acquisition- F.Y., Ş.D.Ö., Ö.Y., C.C.; Data Analysis/Interpretation- B.K., B.N.S., A.Ö.; Drafting Manuscript- B.K., F.Y., Ş.D.Ö., Ö.Y., C.C., A.Ö.; Critical Revision of Manuscript- E.M.Ş., B.N.S.; Approval and Accountability- B.K., F.Y., Ş.D.Ö., Ö.Y., C.C., B.N.S., A.Ö., E.M.Ş.

Conflict of Interest: Authors declared no conflict of interest

Financial Disclosure: Authors declared no financial support.

\section{REFERENCES}

1. Elhai JD, Dvorak RD, Levine JC, Hall BJ. Problematic smartphone use: A conceptual overview and systematic review of relations with anxiety and depression psychopathology. J Affect Disord 2017;207:251-9. [CrossRef]

2. Güler $H$, Şahinkayası $Y$, Şahinkayası $H$. Internet ve mobil teknolojilerin yaygınlaşması: Fırsatlar ve sınırlılıklar. Sos Bilim Derg 2017;7(14):186-207. [CrossRef]

3. De-Sola Gutierrez J, Rodriguez de Fonseca F, Rubio G. Cellphone addiction: A Review. Front Psychiatry 2016;7:175. [CrossRef]

4. Thomée S, Härenstam A, Hagberg M. Mobile phone use and stress, sleep disturbances, and symptoms of depression among young adults - A prospective cohort study. BMC Public Health 2011;11:66. [CrossRef]

5. Noyan CO, Enez Darçın A, Nurmedov S, Yılmaz O, Dilbaz N. Akıllı Telefon Bağımlılığı Ölçeğinin Kısa Formunun üniversite öğrencilerinde Türkçe geçerlilik ve güvenilirlik çalışması. Anadolu Psikiyatr Derg 2015;16(1):73-81. [CrossRef]

6. Kuyucu M. Gençlerde akıllı telefon kullanımı ve akıllı telefon bağımlıığı sorunsalı: "Akıllı telefon(kolik) üniversite gençliği." Glob Media J TR Ed 2017;7(14):328-59.

7. Öngören B. Sosyolojik açıdan sağlıklı beden imgesi. Sos ve Beşeri Bilim Araştırmaları Derg 2015;16(34):25-45. 
8. Doğan T. Sosyal Görünüş Kaygısı Ölçeği'nin (SGKÖ) Türkçe uyarlaması: Geçerlik ve güvenirlik çalışması. Hacettepe Üniversitesi Eğitim Fakültesi Derg 2010;39:151-159.

9. Emirtekin E, Balta S, Sural I, Kircaburun K, Griffiths MD, Billieux J. The role of childhood emotional maltreatment and body image dissatisfaction in problematic smartphone use among adolescents. Psychiatry Res 2019;271:634-9. [CrossRef]

10. Arantes Pagano AL, Araújo GB, Freitas GS, Lopes RG, Azevedo RG, Borges RD. et al. Body perception and anorexic behavior in medical school students: A crosssectional observational study. MedNEXT J Med Health Sci 2021;2(1):66-72. [CrossRef]

11. Tuğlu C, Türe $M$, Dağdeviren $N$, Aktürk Z. Birinci basamak için Beck depresyon tarama ölçeğinin Türkçe çevriminin geçerlik ve güvenirliği. Türkiye Aile Hekim Derg 2005;9(3):117-22.

12. Ulusoy M, Sahın N, Erkmen H. Turkish version of the Beck Anxiety Inventory: Psychometric properties. J Cogn Psychother 1998;12(2):163-72.

13. Kwon M, Kim D-J, Cho H, Yang S. The smartphone addiction scale: Development and validation of a short version for adolescents. PLoS One 2013;8(12):e83558. [CrossRef]

14. Hart TA, Flora DB, Palyo SA, Fresco DM, Holle C, Heimberg RG. Development and examination of the social appearance anxiety scale. Assessment 2008;15(1):48-59. [CrossRef]

15. Field A. Discovering Statistics Using IBM SPSS Statistics. 5th ed. SAGE Publications Ltd.; 2018.

16. Aljomaa SS, Al.Qudah MF, Albursan IS, Bakhiet SF, Abduljabbar AS. Smartphone addiction among university students in the light of some variables. Computers in Human Behavior 2016;61:155-64. [CrossRef]

17. Halayem S, Nouira O, Bourgou S, Bouden A, Othman S, Halayem M. The mobile: a new addiction upon adolescents. Tunis Med 2010;88(8):593-6.

18. Yahyazadeh S, Fallahi-Khoshknab M, Norouzi K, Dalvandi A. The prevalence of smartphone addiction among students in medical sciences universities in Tehran 2016. Advances in Nursing \& Midwifery 2017;26(94):1-10.

19. Lin $Y H$, Lin $Y C$, Lee $Y H$, Lin $P H$, Lin $S H$, Chang $L R$, et al. Time distortion associated with smartphone addiction: Identifying smartphone addiction via a mobile application (App). J Psychiatr Res 2015;65:139-45. [CrossRef]
20. Demirci K, Akgönül $M$, Akpinar A. Relationship of smartphone use severity with sleep quality, depression, and anxiety in university students. J Behav Addict 2015;4(2):8592. [CrossRef]

21. Jones, T. Students' cell phone addiction and their opinions. Elon Journal of Undergraduate Research in Communications 2014;5.1.

22. Augner C, Hacker GW. Associations between problematic mobile phone use and psychological parameters in young adults. Int J Public Health 2012;57(2):437-41. [CrossRef]

23. Harwood J, Dooley J, Scott A, Joiner R. Constantly connected-The effects of smart-devices on mental health. Computers in Human Behavior 2014;34:267-72. [CrossRef]

24. Santos VA, Freire R, Zugliani M, Cirillo P, Santos HH, Nardi $A E$, et al. Treatment of internet addiction with anxiety disorders: Treatment protocol and preliminary before-after results involving pharmacotherapy and modified cognitive behavioral therapy. JMIR Res Protoc 2016;5(1):e46. [CrossRef]

25. Wan Ismail WS, Sim ST, Tan KA, Bahar N, Ibrahim $N$, Mahadevan $R$, et al. The relations of internet and smartphone addictions to depression, anxiety, stress, and suicidality among public university students in Klang Valley, Malaysia. Perspect Psychiatr Care 2020;56(4):949-55. [CrossRef]

26. Claes L, Hart TA, Smits D, Van den Eynde F, Mueller A, Mitchell JE. Validation of the social appearance anxiety scale in female eating disorder patients. Eur Eat Disord Rev 2012;20(5):406-9. [CrossRef]

27. Grogan S. Body Image: Understanding Body Dissatisfaction in Men, Women and Children. 3rd ed. Routledge; 2016.

28. Forbes GB, Adams-Curtis LE, Rade B, Jaberg P. Body dissatisfaction in women and men: The role of gendertyping and self-esteem. Sex Roles 2001;44(7-8):461-84. [CrossRef]

29. Gültzow T, Guidry JPD, Schneider F, Hoving C. Male Body Image Portrayals on Instagram. Cyberpsychology, Behav Soc Netw 2020;23(5):281-9. [CrossRef] 